\title{
PRODUCTION AND EVALUATION OF NONTRADITIONAL PRODUCTS FROM LEMON GRASS
}

\author{
ASSOUS, M.T.M., K.H.M. EL-WASEIF and G.B.A.GADO \\ Food Technology Research Institute, ARC, Giza , Egypt
}

(Manuscript received 18 December 2012)

\begin{abstract}
This study was carried out to produce products having high nutritional value from lemon grass with valencia orange, Egyptian lime and cantaloupe juices available all the year besides studying the factors affecting on quality of products after processing and during storage. Blends were prepared from lemon grass extract with orange, lime and cantaloupe juices at a ratio of 1:1, 2:1 and 3:1(wt:wt), respectively .Results indicate that total carbohydrates, fat, ash, total phenols and ascorbic acid contents of lemon grass leaves were $75.73,4.15,9.47,3.76 \%$ and $175.11 \mathrm{mg} / 100 \mathrm{~g}$ (on dry weight basis), respectively. Results illustrate that total soluble solids (T.S.S.) of blends ranged from $15-15.3 \%$, total sugars from 79.51 to $88.86 \%$, ash content $(1.83-2.56 \%)$, total phenols content $(0.410-0.812 \%)$ and ascorbic acid content $(23.02-152.4 \mathrm{mg} / 100 \mathrm{~g})$ on dry weight basis. Results show that statistical analyses for sensory evaluation of nectars were accepted for orange juice at a ratio of 2:1 and lemon grass extract: lime juice at a ratio of 3:1.The chemical composition of products was slightly affected by storage, while statistical analyses for sensory evaluation of nectars ascertained that they were accepted till 9 months of storage at room temperature. Also, results show that total bacterial count was less than $10 \mathrm{cfu} / \mathrm{gfor}$ nectars during storage.

Key words : lemon grass, extract, juice, nectar, storage

Email, assous2010@yahoo.com
\end{abstract}

\section{INTRODUCTION}

Lemon grass (Cymbopogon citrates) of the poaceae family is cultivated in tropical and semi-tropical areas (Ravinder et al., 2010). It is one of aromatic herb of interest, widely used in tropical and subtropical countries in human foods and tea preparation and it contains essential oils which are used in perfume and pharmaceutical industries(Koshima et ai., 2003 and wanapat et al ., 2008).

This species commonly cultivated for the fine fragrance of the leaves which are often used for flavoring custard. When fresh and young, leaves are consumed in salads and are used to prepare traditional meat recipes. The white center of the leaves is also used to impart a flavorto curries. The tea made from this grass is considered a whole some and refreshing beverage that is much appreciated and largely consumed in 
North Africa (Khadri et al., 2010) as a substitute for tea, due to its pleasant aroma and taste.

Also, Asaolu et al., (2009) showed that Cymbopogon citrates is a plant of considerable economic importance which forms the bedrock farming systems in many countries where they are cultivated for commercial purpose.

Olotade (2009) reported that crude fiber, fat and carbohydrate contents of dried Cymbopogon citrates leaves were 27.72, 1.25 and $38.44 \%$ (on fresh weight basis), respectively. Total of 19 constituents representing $95.47 \%$ of the essential oil were identified :piperitone(72.44\%),elemol(9.43\%),a-eudesmol( $4.34 \%)$, limonene $(2.45 \%)$ and $\beta-(1.26 \%)$ were the main components comprising $88.92 \%$ of the oil. The antimicrobial results show that the essential oil of Cymbopogon citrates strongly inhibited the growth of the test bacteria (Selim, 2011).

Garcíaet al., (2001)) and Dyabet al., (2010) reported that blending treatments of pulps or juices of fruits and vegetables with other pulps or juices from fruits and vegetables led to raising its acceptability for consumer and increasing in total phenolic compounds and antioxidant activity.

The objectives of this study were the preparation and evaluation of nectar formulas which contain lemon grass with different juices.

\section{MATERIALS AND METHODS}

\section{Materials:-}

Lemon grass (Cymbopogoncitrates) was obtained from the Horticultural Research Inst., Agric., Res. Center, Giza, Egypt. Valencia oranges(Citrus sinensis),called summer oranges, Egyptian lime(Citrus aurantifolia)and Galia cantaloupe (Cucmis melo L.) were purchased from local market .Sucrose was obtained from Sugar and Integrated Industries Co., Egypt.

\section{Methods:-}

\section{Processing methods:-}

\section{Preparation of juices and lemon grass extract}

\section{Orange and lime juices}

Fruits were sorted, washed, cut into halves, pressed by hydraulic laboratory press, then the resultant juices were strained through anylon sieve.

\section{Cantaloupe juice}

Cantaloupe vegetables were sorted washed peeled, divided into two equal portions to remove the seeds. Water was added to the portions at a ratio1:2 (vol: wt)and mixed with electric pulper, then screened through a nylon sieve. 


\section{Lemon grass extract}

Lemon grass leaves were extracted with a ratio of lemon grass to water 1:4(wt: vol) and boiled in reflecting condenser for $30 \mathrm{~min}$., then the mixtures were filtered through a nylon sieve.

\section{Preparation of nectar formulas from lemon grass extract with different juices}

Lemon grass extract was mixed with juices at different ratios as follows: Control (lemon grass extract without the addition of juices).

Treatment (1) Lemon grass extract: valencia orange juice at a ratio of 1:1(wt: wt). Treatment (2) Lemon grass extract: valencia orange juice at a ratio of 2:1(wt: wt). Treatment (3) Lemon grass extract: valencia orange juice at a ratio of 3:1(wt: wt). Treatment (4) Lemon grass extract: lime juice at a ratio of 1:1(wt: wt). Treatment (5) Lemon grass extract: lime juice at a ratio of 2:1(wt: wt). Treatment (6) Lemon grass extract: lime juice at a ratio of 3:1(wt: wt). Treatment (7) Lemon grass extract: cantaloupe juice at a ratio of $1: 1$ (wt: wt). Treatment (8) Lemon grass extract: cantaloupe juice at a ratio of 2:1(wt: wt). Treatment (9) Lemon grass extract: cantaloupe juice at a ratio of 3:1(wt: wt). Nectar formulas and control treatments raised total soluble solids (T.S.S) to $\geq 15 \%$ by sucrose. Then the nectars were pasteurized at $85 \square$ for $10 \mathrm{~min}$, cooled and stored at room temperature for analysis.

\section{Analytical methods:-}

\section{Chemical analysis}

Moisture content, $\mathrm{pH}$ value total soluble solids (T.S.S.), total titratable acidity, reducing, non-reducing and total sugars, ash, crude fiber, fat, total phenols and total carbohydrates contents were determined according to the procedure described in the A.O.A.C. (2005). Chlorophyll a, b and total caroteniods were determined according to Askar and Treptow (1993)

\section{Microbiological evaluation}

Total bacterial counts as well as yeast and mould counts were determined according to the method described by APHA (1992).

\section{Sensory evaluation of samples:}

The nectars were sensory evaluated according to the method described by García et al., (2001).

\section{Statistical analysis}

The obtained data of sensory evaluation of nectars were statistically analyzed according to ANOVA procedure of the SPSS statistical package (SPSS, 1990). 


\section{RESULTS AND DISCUSSION}

\section{Physical and chemical constituents of fresh lemon grass leaves}

Results in table (1) show that moisture content, TSS, and pH value of lemon grass leaves were $80.47 \%, 4.3 \%$ and $5.76 \%$, respectively. Results in table (1) indicate that total carbohydrates, crude fiber, fat and ash contents were 75.73, 52.02, 4.15 and $9.47 \%$ on dry weight basis. These results are in agreement with those reported by Naguib (2002)and Omer et al.,(2010).Also, results in the same table illustrate that total phenols of fresh leave lemon grass was $3.76 \%$ on dry weigh basis .Yoo et al., (2008) reported that total phenols of lemon grass were $662 \mathrm{mg}$ GAE/100 g (gallic acid equivalents per $100 \mathrm{~g}$ of fresh herb).

Table 1. Physical and chemical constituents of fresh lemon grass leaves.

\begin{tabular}{|ll|c|}
\hline properties & $\%$ & Value \\
\hline Moisture content & $\%$ & 80.47 \\
\hline TSS & $\%$ & 4.30 \\
\hline pH value & $\%$ & 5.76 \\
\hline Total acidity* (as citric acid) & 0.732 \\
\hline Reducing sugars* & $\%$ & 6.91 \\
\hline Non-reducing sugars* & $\%$ & 2.10 \\
\hline Total sugars* & $\%$ & 9.01 \\
\hline Crude fiber* & $\%$ & 52.02 \\
\hline Total carbohydrates* & $\%$ & 75.73 \\
\hline Fat* & $\%$ & 4.15 \\
\hline Ash* & $\%$ & 9.47 \\
\hline Total phenols* & $\%$ & 3.76 \\
\hline Chlorophyll $*(\mathrm{a})$ & & 19.20 \\
\hline Chlorophyll* $(\mathrm{b})$ & & 10.54 \\
\hline Total carotenoides* $\mathrm{mg} / 100 \mathrm{~g}$ & & 1.43 \\
\hline Ascorbic acid* mg/100g & & 175.11 \\
\hline
\end{tabular}

* On dry weigh basis

Refaat and Balbaa(2001) and Mirza et al., (2003)illustrate that percentage of the different components in lemon grass differed with fertilization and environmental conditions prevailing during growth .

Physical and chemical constituents of juices and lemon grass extract

Physical and chemical properties of oranges, lime, cantaloupe juices as well as fresh lemon grass extract are presented in Table (2). The moisture contents of 
different juices ranged from 87.00 to $98.11 \%$.From the same table it could be noticed that the highest total acidity of lime juice followed by other juices while, ascorbic acid content of orange juice was higher than that of other ones. From the same results in Table (2) it could be noticed that ash and total phenols content were the highest in lemon grass extract from other juices. Guimarães, et. al. (2010) found that reducing sugars of orange and lime juices were 63.07 and $22.43 \mathrm{mg} / \mathrm{g}$ extract, phenolics 12.41 and $11.17 \mathrm{mgGAE} / \mathrm{g}$ extract, caroteniods 0.8 and $0.6 \mathrm{ug} / \mathrm{g}$ extract and ascorbic acid 523.89 and $417.44 \mathrm{ug} / \mathrm{g}$ extract, respectively .Total sugars in lemon grass extract were the lowest comparedto other juices. These results are in agreement with those found by Kelebek, et. al. (2009) and Solval, et al.,(2012).

Table 2. Some physical and chemical constituents of juices and lemon grass.

\begin{tabular}{|l|c|c|c|c|}
\hline \multicolumn{1}{|c|}{ Juices } & $\begin{array}{l}\text { Valencia } \\
\text { orange } \\
\text { juice }\end{array}$ & $\begin{array}{c}\text { Lime } \\
\text { juice }\end{array}$ & $\begin{array}{c}\text { Cantaloupe } \\
\text { juice }\end{array}$ & $\begin{array}{c}\text { Lemon } \\
\text { grass } \\
\text { extract }\end{array}$ \\
\hline Moisture \% & 87.00 & 92.55 & 92.90 & 98.11 \\
\hline TSS \% & 12.4 & 7.00 & 6.30 & 1.20 \\
\hline pH value & 4.00 & 2.66 & 6.18 & 5.85 \\
\hline Total acidity*(ascitricacid)\% & 3.06 & 29.58 & 0.123 & 1.85 \\
\hline Reducing sugars*\% & 37.47 & 12.89 & 41.48 & 23.80 \\
\hline Non-reducing sugars*\% & 46.40 & 19.41 & 17.77 & 5.31 \\
\hline Total sugars*\% & 83.87 & 32.30 & 59.25 & 29.11 \\
\hline Ash*\% & 3.51 & 4.26 & 7.03 & 15.34 \\
\hline Total phenols*\% $\%$ & 0.285 & 0.281 & 0.148 & 6.87 \\
\hline Totalcarotenoides* $\mathrm{mg} / 100 \mathrm{~g}$ & 5.21 & 0.769 & 4.44 & 2.64 \\
\hline Ascorbic acid* mg/100g & 425.43 & 308.99 & 63.95 & 224.86 \\
\hline
\end{tabular}

*On dry weight basis.

\section{Physical and chemical constituents of nectar formulas.}

The prepared nectar formulas reached up to15 \%T.S.S .according to the Egyptian standards(1992). Results in Table (3) indicate that T.S.S value and moisture contents of the different nectars ranged from 15 to $15.30 \%$ and from 83.76 to $84.61 \%$, respectively. Results in Table (3) indicate that increasing lemon grass extract to different juices at a ratio from 1: 1 to $3: 1$ gradually reduce total acidity content of the prepared nectars. Results in table (3) illustrated that total sugars of nectars ranged from 79.51 to $91.25 \%$ (on dry weight basis). 
Table 3. physical and chemical constituents of nectars formulas.

\begin{tabular}{|c|c|c|c|c|c|c|c|c|c|c|}
\hline properties & Cont. & $\mathrm{T}_{1}$ & $\mathrm{~T}_{2}$ & $\mathrm{~T}_{3}$ & $\mathrm{~T}_{4}$ & $\mathrm{~T}_{5}$ & $\mathrm{~T}_{6}$ & $\mathrm{~T}_{7}$ & $\mathrm{~T}_{8}$ & $\mathrm{~T}_{9}$ \\
\hline Moisture \% & 84.41 & 84.45 & 84.61 & 84.37 & 84.33 & 84.22 & 84.42 & 83.76 & 83.78 & 83.85 \\
\hline TSS $\quad \%$ & 15.0 & 15.1 & 15.0 & 15.3 & 15.0 & 15.2 & 15.1 & 15.1 & 15.2 & 15.3 \\
\hline $\mathrm{pH}$ value & 5.83 & 4.19 & 4.20 & 4.35 & 2.85 & 2.95 & 3.13 & 5.95 & 6.05 & 6.10 \\
\hline $\begin{array}{l}\text { Total } \\
\text { acidity*(as } \\
\text { citric acid)\% }\end{array}$ & 0.216 & 1.30 & 0.95 & 0.76 & 7.88 & 5.32 & 4.12 & 0.134 & 0.164 & 0.179 \\
\hline $\begin{array}{l}\text { Reducing } \\
\text { sugars } * \%\end{array}$ & 5.80 & 20.81 & 17.04 & 14.26 & 12.42 & 10.98 & 10.13 & 15.27 & 12.65 & 11.16 \\
\hline $\begin{array}{l}\text { Non-reducing } \\
\text { sugars*\% }\end{array}$ & 85.45 & 62.28 & 69.83 & 74.60 & 67.09 & 72.58 & 75.81 & 68.14 & 74.96 & 77.40 \\
\hline $\begin{array}{l}\text { Total } \\
\text { sugars*\% }\end{array}$ & 91.25 & 83.09 & 86.87 & 88.86 & 79.51 & 83.56 & 85.94 & 83.41 & 87.61 & 88.56 \\
\hline Ash*\% & 1.79 & 2.28 & 2.14 & 2.05 & 2.01 & 1.92 & 1.83 & 2.56 & 2.37 & 2.22 \\
\hline $\begin{array}{l}\text { Total } \\
\text { phenols*\% }\end{array}$ & 0.71 & 0.410 & 0.500 & 0.570 & 0.485 & 0.581 & 0.812 & 0.421 & 0.550 & 0.621 \\
\hline $\begin{array}{l}\text { Total } \\
\text { carotenoides* } \\
\mathrm{mg} / 100 \mathrm{~g}\end{array}$ & 0.28 & 1.95 & 1.45 & 0.97 & 0.354 & 0.320 & 0.345 & 1.22 & 0.952 & 0.791 \\
\hline $\begin{array}{l}\text { Ascorbicacid* } \\
\mathrm{mg} / 100 \mathrm{~g}\end{array}$ & 24.29 & 152.4 & 110.9 & 86.75 & 86.63 & 65.30 & 56.36 & 23.46 & 23.39 & 23.02 \\
\hline
\end{tabular}

*On dry weight basis. Cont. (lemon grass extract without addition of juices)

$\mathrm{T}_{1}$ (Lemon grass extract: Orange juice, 1:1), $\mathrm{T}_{2}$ (Lemongrass extract: Orange juice, 2:1), $T_{3}$ (Lemongrass extract: Orange juice, 3:1), $T_{4}$ (Lemongrass extract: lime juice, $1: 1), T_{5}$ (Lemongrass extract: lime juice, $\left.2: 1\right), T_{6}$ (Lemongrass extract: lime juice, $3: 1), T_{7}$ (Lemon grassextract: cantaloupe juice, 1:1), $T_{8}$ (Lemongrass extract: cantaloupe juice, 2:1), $T_{9}$ (Lemon grassextract: cantaloupe juice, 3:1).

On the other hand, results in the same Table (3) shows that, non reducing sugars were higher than that reducing sugars of nectars due to the addition of sucrose to 
increase the T.S.S.to $15 \%$.Ascorbic acid, total phenols and total carotenoides contents are one of the most important parameters to be considered in determining the quality of formulas because it is considered the main factors of antioxidant activity. Results in Table (3) indicate that ascorbic acid and total carotenoides of Valencia orange juice with lemon grass extract were higher than that of other ones due to its high contents of original juice.

\section{Effect of mixing lemon grass extract with different juices on sensory evaluation.}

The color, taste, odor and overall acceptability of natural nectars formulas from lemon grass extract without and with Valencia oranges, lime and cantaloupe juices were evaluated. Results in Table (4) indicate that color scores of treatments $\left(T_{1}, T_{2}\right.$ and $\left.T_{6}\right)$ were significantly higher than those of other treatments.

Table 4. Mean score values of sensory evaluation of nectar formulas after preparation.

\begin{tabular}{|l|l|l|l|l|}
\multicolumn{1}{|c|}{ Parameters } & Color & Taste & Odor & $\begin{array}{l}\text { overall } \\
\text { acceptability }\end{array}$ \\
\cline { 2 - 5 } Treatments & & & & \\
\hline Control & $5.3^{\mathrm{c}} \pm 0.66$ & $6.8^{\mathrm{bc}} \pm 0.54$ & $8.0^{\mathrm{a}} \pm 0.22$ & $5.5^{\mathrm{bc}} \pm .045$ \\
\hline $\mathrm{T}_{1}$ & $9.0^{\mathrm{a}} \pm 0.45$ & $7.8^{\mathrm{bc}} \pm 0.63$ & $8.0^{\mathrm{a}} \pm .41$ & $6.0^{\mathrm{b}} \pm 0.70$ \\
\hline $\mathrm{T}_{2}$ & $9.0^{\mathrm{a}} \pm 0.63$ & $8.8^{\mathrm{a}} \pm 0.12$ & $7.6^{\mathrm{ab}} \pm 0.57$ & $9.0^{\mathrm{a}} \pm 0.44$ \\
\hline $\mathrm{T}_{3}$ & $5.8^{\mathrm{c}} \pm 0.49$ & $8.2^{\mathrm{ab}} \pm 0.13$ & $7.6^{\mathrm{ab}} \pm 0.43$ & $5.6^{\mathrm{bc}} \pm 0.89$ \\
\hline $\mathrm{T}_{4}$ & $5.6^{\mathrm{c}} \pm 0.94$ & $5.4^{\mathrm{c}} \pm 0.89$ & $8.0^{\mathrm{a}} \pm 0.33$ & $5.0^{\mathrm{bc}} \pm 0.58$ \\
\hline $\mathrm{T}_{5}$ & $7.0^{\mathrm{b}} \pm 0.71$ & $7.9^{\mathrm{bc}} \pm 0.69$ & $7.6^{\mathrm{ab}} \pm 0.67$ & $6.0^{\mathrm{b}} \pm 0.70$ \\
\hline $\mathrm{T}_{6}$ & $9.2^{\mathrm{a}} \pm 0.73$ & $8.6^{\mathrm{a}} \pm .59$ & $7.5^{\mathrm{ab}} \pm 0.51$ & $8.5^{\mathrm{a}} \pm 0.66$ \\
\hline $\mathrm{T}_{7}$ & $7.0^{\mathrm{b}} \pm 0.70$ & $6.0^{\mathrm{c}} \pm 0.72$ & $5.6^{\mathrm{bc}} \pm 0.89$ & $5.0^{\mathrm{bc}} \pm 0.70$ \\
\hline $\mathrm{T}_{8}$ & $6.1^{\mathrm{bc}} \pm 0.73$ & $7.0^{\mathrm{c}} \pm 0.58$ & $5.6 \mathrm{~b}^{\mathrm{c}} \pm 0.46$ & $4.4^{\mathrm{c}} \pm 0.54$ \\
\hline $\mathrm{T}_{9}$ & $6.0^{\mathrm{bc}} \pm 0.68$ & $6.9^{\mathrm{bc}} \pm 0.43$ & $4.6^{\mathrm{c}} \pm 0.75$ & $4.2^{\mathrm{c}} \pm 0.82$ \\
\hline
\end{tabular}

Means with the same column are not significantly different at 0.05 level of significance.

Cont.( lemon grassextract without addition of juices),$T_{1}$ (Lemongrass extract: Orange juice, 1:1), $T_{2}$ (Lemongrass extract: Orange juice, 2:1), $T_{3}$ (Lemongrass extract: Orange juice, 3:1), $T_{4}$ (Lemongrass extract: lime juice, $\left.1: 1\right), T_{5}$ (Lemon grassextract: lime juice, 2:1), $T_{6}$ (Lemon grassextract: lime juice, $3: 1$ ), $T_{7}$ (Lemongrass extract: 
cantaloupe juice, 1:1), $\mathrm{T}_{8}$ (Lemon grassextract: cantaloupe juice, 2:2), $\mathrm{T}_{9}$ (Lemon grassextract: cantaloupe juice, 3:1).

From the same table (4) it could be seen that taste scores of the treatments $\left(T_{2}\right.$ and $T_{6}$ ) were significantly higher than those of other formulas. It is obvious that no significant difference was found in odor of products from lemon grass with lime or orange nectars formulas. Inyang and Abah (1997) reported that blending could lead to the production of delightful and delicious beverages with improved organoleptic quality and a high nutritive value. The high scores in the overall acceptability were found in formulas $\left(T_{2}\right.$ and $\left.T_{6}\right)$. It could be concluded that lemon grass with orange juice at a ratio of 2:1orlemon grass with lime juice at a ratio of 3:1 gave the best record and highest acceptability, thus, these formulas were selected among all studies to follow their quality parameters during storage.

\section{Effect of storage period on physical and chemical constituents of nectar} formulas at room temperature.

Results in table (5) show physical and chemical constituents of formulas nectar ( $T_{2}$ and $T_{6}$ ) during storage. Moisture content of nectar formulas was almost stable during storage periods. Total soluble solids slightly showed a decrease during storage from 0.6 to $1.3 \%$ of the initial value. Results in table (5) indicate that total acidity content was accompanied by a gradual and slight decrease from 0.95 to $0.87 \%$ of Lemon grass extract: orange juice $2: 1\left(T_{2}\right)$ and from 4.12 to $3.78 \%$ of lemon grass extract: lime juice 3:1 $\left(T_{6}\right)$, respectively. These decrements in total acidity could be attributed mainly to the breakdown of ascorbic acid during storage. Results in table (5) indicate that reducing sugars highly increased during storage periods. This increase of reducing sugars content may be related to the high level of total acidity contents in the products that hydrolyzed the non- reducing sugars during storage.

Also, total sugars slightly decreased during storage. This decrement could be due to reducing sugars reaction with amino acids. Results in Table (5) indicate that ascorbic acid of nectars decreased during storage. These results are in agreement with those found by Klimczak et al., (2007). On the other hand, the rate of ascorbic acid reduction during storage of lemon grass with lime juice was lower than that of nectar with orange juice.

\section{Effect of storage period on microbial counts of nectar formulas at room temperature.}

Total bacterial as well as yeast and mold counts were absent after processing till 6 months from storage while, total bacterial counts slightly increased during storage but still lower than $10 \mathrm{cfu} / \mathrm{g}$ of all products at the end of storage period. 
These results are in accordance with those reported by Chao and Young (2000),Ravinderet al., (2010) and Selim (2011) who found that lemon grass essential oil was active against food storage fungi and the inhibition of the growth of food spoilage, food -borne pathogens .

Table 5. physical and chemical constituents of nectar formulas during storage at room temperature.

\begin{tabular}{|c|c|c|c|c|c|c|c|c|}
\hline Nectar formulas & \multicolumn{4}{|c|}{$\mathrm{T}_{2}$} & \multicolumn{4}{|c|}{$\mathrm{T}_{6}$} \\
\hline storage period (month) & $\begin{array}{l}\text { Zero } \\
\text { time }\end{array}$ & 3 & 6 & 9 & $\begin{array}{l}\text { Zero } \\
\text { time }\end{array}$ & 3 & 6 & 9 \\
\hline Moisture \% & 84.61 & 84.60 & 84.69 & 84.70 & 84.42 & 84.45 & 84.53 & 84.58 \\
\hline TSS $\%$ & 15.0 & 15.0 & 14.9 & 14.9 & 15.1 & 15.0 & 14.9 & 14.9 \\
\hline $\mathrm{pH}$ value & 4.20 & 4.25 & 4.28 & 4.34 & 3.13 & 3.20 & 3.25 & 3.30 \\
\hline $\begin{array}{l}\text { Total acidity*(as citric } \\
\text { acid)\% }\end{array}$ & 0.95 & 0.90 & 0.88 & 0.87 & 4.12 & 4.08 & 3.90 & 3.78 \\
\hline Reducing sugars $* \%$ & 17.04 & 20.54 & 21.79 & 21.51 & 10.13 & 14.91 & 17.83 & 19.08 \\
\hline Non-reducing sugars $* \%$ & 69.83 & 65.01 & 63.22 & 62.75 & 75.81 & 70.11 & 66.45 & 64.45 \\
\hline Total sugars $* \%$ & 86.87 & 85.55 & 85.01 & 84.26 & 85.94 & 85.02 & 84.28 & 83.53 \\
\hline Total phenols $* \%$ & 0.500 & 0.452 & 0.442 & 0.425 & 0.812 & 0.743 & 0.730 & 0.715 \\
\hline $\begin{array}{l}\text { Total carotenoides* } \\
\mathrm{mg} / 100 \mathrm{~g}\end{array}$ & 1.45 & 1.377 & 1.348 & 1.305 & 0.345 & 0.310 & 0.293 & 0.276 \\
\hline Ascorbicacid* mg/100g & 110.9 & 91.38 & 82.17 & 77.63 & $56 . .36$ & 47.85 & 45.04 & 42.22 \\
\hline
\end{tabular}

* On dry weight basis, $T_{2}$ (Lemongrass extract: Orange juice, 2:1), $T_{6}$ (Lemongrass extract: lime juice, $3: 1$ )

\section{Effect of storage period on sensory evaluation of nectar formulas at room temperature.}

Results in Table (6) show that mean scores of sensory evaluation of all products decreased by storage. However, the mean scores of all products were higher than that of 6.95 scores after 9 month of storage at room temperature indicating superior quality.

Hence it could be recommended to produce nectar formulas (lemon grass with orange and lime juices) at a ratio of $2: 1$ or $3: 1$, respectively to give excellent product. 
Table 6. Mean score values of sensory evaluation of nectar formulas during storage at room temperature.

\begin{tabular}{|c|c|c|c|c|c|c|c|c|}
\hline Nectar formulas & \multicolumn{4}{|c|}{$\mathbf{T}_{\mathbf{2}}$} & \multicolumn{4}{|c|}{$\mathbf{T}_{6}$} \\
\hline $\begin{array}{l}\text { storage period } \\
\text { (month) }\end{array}$ & $\begin{array}{l}\text { Zero } \\
\text { Time }\end{array}$ & 3 & 6 & 9 & $\begin{array}{l}\text { Zero } \\
\text { time }\end{array}$ & 3 & 6 & 9 \\
\hline Color & $\begin{array}{r}9.0^{\mathrm{a}} \\
\pm 0.63 \\
\end{array}$ & $\begin{array}{l}8.04^{\mathrm{ab}} \\
\pm 0.54 \\
\end{array}$ & $\begin{array}{r}8.0^{\mathrm{ab}} \\
\pm 0.43 \\
\end{array}$ & $\begin{array}{l}7.84^{\mathrm{ab}} \\
\pm 0.81 \\
\end{array}$ & $9.2^{\mathrm{a}} \pm 0.73$ & $\begin{array}{l}8.23^{a} \\
\pm 0.73 \\
\end{array}$ & $\begin{array}{l}8.13^{\mathrm{ab}} \\
\pm 0.73 \\
\end{array}$ & $\begin{array}{l}8.01^{a b} \\
\pm 0.73 \\
\end{array}$ \\
\hline Taste & $8.8^{\mathrm{a}} \pm 0.12$ & $\begin{array}{l}8.31^{\mathrm{a}} \\
\pm 0.42 \\
\end{array}$ & $\begin{array}{l}8.01^{\mathrm{ab}} \\
\pm 0.62 \\
\end{array}$ & $\begin{array}{l}7.82^{\mathrm{b}} \\
\pm 0.32 \\
\end{array}$ & $8.6^{\mathrm{a}} \pm 0.59$ & $\begin{array}{l}8.12^{\mathrm{a}} \\
\pm 0.41 \\
\end{array}$ & $\begin{array}{l}7.84^{\mathrm{ab}} \\
\pm 0.53 \\
\end{array}$ & $\begin{array}{l}7.65^{\mathrm{b}} \\
\pm 0.72 \\
\end{array}$ \\
\hline Odor & $7.6^{\mathrm{ab}} \pm 0.57$ & $\begin{array}{l}7.13^{\mathrm{b}} \\
\pm 0.77\end{array}$ & $\begin{array}{l}7.11^{\mathrm{b}} \\
\pm 0.49\end{array}$ & $\begin{array}{l}7.04^{b} \\
\pm 0.66\end{array}$ & $7.5^{\mathrm{ab}} \pm 0.51$ & $\begin{array}{l}7.03^{b} \\
\pm 0.77\end{array}$ & $\begin{array}{l}7.0^{\mathrm{b}} \\
\pm 0.63\end{array}$ & $\begin{array}{l}6.95^{\mathrm{b}} \\
\pm 0.89\end{array}$ \\
\hline $\begin{array}{l}\text { Overall } \\
\text { acceptability }\end{array}$ & $9.0^{\mathrm{a}} \pm 0.44$ & $\begin{array}{l}8.45^{\mathrm{a}} \\
\pm 0.81\end{array}$ & $\begin{array}{l}8.16^{a b} \\
\pm 0.34\end{array}$ & $\begin{array}{l}8.06^{\mathrm{ab}} \\
\pm 0.52\end{array}$ & $8.5^{\mathrm{a}} \pm 0.66$ & $\begin{array}{l}8.12^{a} \\
\pm 0.36\end{array}$ & $\begin{array}{l}7.93^{\mathrm{ab}} \\
\pm 0.52\end{array}$ & $\begin{array}{l}7.6^{\mathrm{ab}} \\
\pm 0.49\end{array}$ \\
\hline
\end{tabular}

Means with the same column are not significantly different at 0.05 level of significance.

$\mathrm{T}_{2}$ (Lemongrass extract: Orange juice, 2:1), $\mathrm{T}_{6}$ (Lemon grass extract: lime juice, 3:1)

\section{REFERENCES}

1. A.P.H.A. 1992. Standard methods for the examination of dairy product. Americanpublic Health Association. Inc. 16th Ed., Washington, D.C.

2. A.O.A.C. 2005. Official Methods of the Analysis of AOAC. International 18th Edition, Published by AOAC International. Maryland 20877- 2417. USA.

3. Asaolu,M.F.,Oyeyemi,O.A. and Olanlokun , J.O. 2009. Chemical composition ,phytochemical constituents and in vitro biological activity of various extracts of Cymbopogon citrates. Pakistan J. of Nutrion 8(12):1920-2009.

4. Askar, A. and Treptow, H. 1993. Quality assurance in tropical fruit processing. Springer-Verlag, Berlin, Heidelberg, New York, London, Paris.

5. Chao,S.C.and Young, D.G. 2000. Screeing for inhibitory activity of essential oils on selected bacteria ,fungi and viruses. J. Esent. Oil.,12,639-649.

6. Dyab, A.S., Soliman, S.A., Bahlol,H.E., Mahmoud, M.H.M. and Radi,O.M.M. 2010. Effect of adding papaya,pumpkin and sweet potato to mango pulp on some bioactive substances .Annals of Agric. Sci., Moshtohor ,48(4):13-22. 
7. Egyptian Standard 1992. Nectars for certain citrus fruits preserved exclusinely by physical means. No. 2239. Egyptian Organization for Standardization and Quality Control.

8. García.A.V. , Bognàr,P.B. and Tauscher.B. 2001. Antioxidative capacity, nutrient content and sensory qualityof orange juice and an orange-lemon-carrot juice product after highpressure treatment and storage in different packaging.Eur Food Res Technol ,213:290-296

9. Guimaraes, R., Barros, L., Barreira , J.C.m.,Sousa,M.J. and Carvalho, A.M. 2010. Targeting excessive free radicals with peels and Juices of citrus fruits: Grape fruit, lemon, lime and orange. Food and Chemicals Toxicology, 48: 99-106.

10. Inyang,U.E. and Abah,U.J. 1997. Chemical composition and organoleptic evaluationof juice from steamed cashew apple blended with orange uice.Plant Foods for Human Nutrition. 50: 295-300.

11. Klimczak,I.,Malecka,M.,Szlachta,M. and Gliszczynska-wiglo,A. 2007. Effect of storage on the content of polyphenols, vitamin $\mathrm{C}$ and the antioxidant activity of orange juices .J.Food and Analysis .20,313-322.

12. Kelebek, H., selli, S., Canbas, A. and Cabaroglu, T. 2009. HPLC determination of organic acids, sugars, phenolic compositions and antioxidant capacity of orange juice and orange wine made from a Turkish cv. Kozan. Microchemical Journal, 91:187-192.

13. Khadri,A., Neffati,M., Smiti,S., Fale,P., Lino,R., Serralheiro,L. and Arau,M. 2010. Antioxidant, antiacetylcholinesterase and antimicrobial activities of Cymbopogon schoenanthus L. Spreng (lemon grass) from Tunisia. LWT - Food Science and Technology,43,331-336.

14. Koshima ,F.A.T.,Ming,L.C., Marques,M.O.M. 2003. Producao de biomassa ,rendimento de oleo essencial e de citral em capim - limao, Cymbogon citrates, com cobertura morta nas estacoes do ano ,11 Simposis Brasileiro de Oleos Essenciais ,IAC, Campinas, SP.

15. Mirza, M. , Kalhoro,M.A.,Yaqeen,Z.,Sarfraz,T.B. and Qadri,R.B. (2003).Physicochemical studies of indigenous diuretic medicinal plants .Pakistan J.of Pharmacology .20 (1):9-16.

16. Naguib,N.Y. 2002. Yield and quality of lemongrass plants (Cymbopogon proximus Stapf) as influenced by farm yard manure and foliar application of bread yea.Annals Agric.Sci. ,Ain Shams Uni. , Cairo,47(3):859-873.

17. Oloyede, O.I. 2009. Chemical profile and antimicrobial activity of Cymbopogon citrates Cymbopogon citrates leaves .J.of Natural Products, 2:98-103. 
18. Omer, H.A.A.,Elallawy ,M.H.,Abdel-Samee,L.D., and Maghraby , N. 2010. Productive performance of rabbits fed on diets containing lemongrass or active dried yeast .American Eurasian J.Agric. \&Envion. Sci.,7(2):179-187.

19. Ravinder, K., Pawan, K.,Gaurav,S., Paramjot,K.,Gagan, S. and pramdeep,K. 2010. Pharmacognostical investigation of Cymbopogon citrates (DC) Stapf. Der Pharmacia Lettre ,2 (2):181-189.

20. Refaat,A.M. and Balbaa, L.K. 2001. Yield and quality of lemongrass plants (Cymbopogon proximus Stapf) in relation to foliar application of some vitamins and microelements.Egypt. J. Hort. 28(1):41-57.

21. SPSS. 1990. SPSS /PC for the IBM PC/XI. Chicago IL. USA.

22. Selim, S.A. 2011. Chemical composition, antioxidant and antimicrobial activity of the essential oil and methanol extract of the Egyptian lemongrass Cymbopogonproximus Stapf. Grasas Y Aceites ,62(1),Enero-Marzo,55-61.

23. Solval, K.M., Sundararajan,S., Alfaro,L.and Sathivel ,S. 2012. Development of cantaloupe (Cucumis melo) juice powders using spray dryingtechnology. LWT Food Science and Technology $46,287-293$.

24. Wanapat,M.,Cherdrhong,A.,Pakdee,P., and Wanapat, S. 2008. Manipulation of rumen ecology by dietary lemongrass (Cymbogon citrates Stapf.) powder supplemenatation.J. of Animal Science., 86,3497 -3503.

25. Yoo , K.M., Lee, C.H. , Lee ,H., Moon , B. , Lee ,C.H. 2008. Relative antioxidant and cytoprotective activities of common herbs. Food Chemistry 106, 929-936. 


\section{انتاج وتقييم منتجات غير تقليدية من حشيثة الليمون}

مصطفى طه محمدى عسوس ، قرى حامد محد الوصيف ، جادو بكر احمد جادو

$$
\text { معهر بحوث تكنولوجيا الأغذية - مركز البحوث الزراعية - الجبيزة - مصر }
$$

تهدف الدر اسة إلى إنتاج نكتار ذو قيمة غذائية عالية ومتو اجد طو ال العام ورخيص السعر من مستخلص حشيشة الليمون مع عصائر برتقال الفالنشيا، الليمون المالح المصرى، الكانتلوب بالإضافة إلى دراسة العو امل التى تؤثر على جودة المنتجات الناتجة بعد التصنيع و أثناء التخزين. تم عمل خلطات من مستخلص حشيشة الليمون الى عصائر برتقال الفالنشيا، الليمون المالح المصرى ، الكانتالوب بنسب 1:1 و 1:2 و 1:3 ( مستخلص حشيشة الليمون الى العصائر الاخرى) على

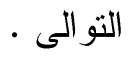
تحتوى حشيشة الليمون على 4.15,75.73، 9.47 ، 3.76\% و 175.11ملجم /100جم على اساس الوزن الجاف لكل من الكربوهيدرات ،الدهون ،الرماد ،الفينولات الكلية وحمض الاسكوربيك على ولى التو الى. اظهرت النتائج ان محتوى الخلطات من المو اد الصلبة الذائية 15 - 15.3\% و 158. وتراوحت السكريات الكلية (79.51 -88.86 \% )و الرماد (1.83- 2.56 \% ) و الفينو لات الكلية (0.410- 0.812\%) وحمض الاسكوربيك (23.02 - 152.4ملجم / 100 جم ) على اساس الوزن الجاف . اوضحت نتائج التحليل الاحصائى للتقييم الحسى للنكتار الناتج ان مسخلص حثيشة الليمون :عصيربرتقال الفالنشيا بنسبة 2 : اومستخلص حشيشة الليمون: عصير الليمون المالح المصرى بنسبة 1: 1: 1 اكانت مقبولة.

تأثر التزكيب الكيماوى تأثر أ طفيفاً مع التخزين بينما كان التحليل الاحصائى لنتائج الاختبارات الحسية مقبولة حسياً حتى بعد 9 شهور من التخزين.وقد دلت النتائج ايضاعلى العدد الكلى للبكتريا

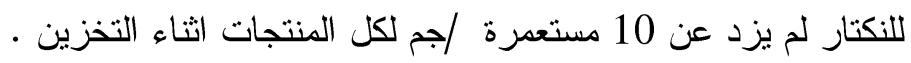

